\title{
Ethnography of the Lebanese Football Clubs
}

\author{
By Axel Maugendre*
}

In Lebanon, parliamentary elections took place in May 2018. After 9 years the ruling Sunni parties and their allies, led by Saad Hariri, were defeated by the political victory of the Shia parties Amal and Hezbollah and their allied party of the new president Michel Aoun. This change in political power sanctioned a situation who had already settled in within the first division of Lebanese men football during the season of 2017/2018. Through a study about football infrastructures, location of stadiums, structural organization of the football federation, the relation between constituencies and club affiliations to political parties and the distinguished role of women football, this article is aiming to analyse the ways in which the development in Lebanese football and politics intertwine.

Keywords: Football, Lebanon, Urban ethnography, women.

\section{Introduction}

To introduce a research which targets a topic in Lebanon, the complex and unique religious and political system of this country has to be explained first. With 4.2 million inhabitants (according to the UN), the political system of Lebanon is based on confessionnalism: 18 recognized sects share political seats in the parliament and positions in different parts of the administration with 4 Muslim sects and 13 Christian sects as well as a Lebanese Jewish community. Each sect practices their own personal matters which are sanctioned by a religious court for such examples as weddings, births, deaths and inheritances. Apart from that Lebanon currently finds itself in a deep crisis regarding the amount of Syrian and Iraqi refugees. According to the UN between 1.2 and 1.5 million refugees came to Lebanon after the beginning of the Syrian civil war, often joining family members who had already settled in Lebanon earlier (Azzam 2015). For the first time in nine years, parliamentary elections in Lebanon took place on the $6^{\text {th }}$ of May in 2018.

The parliamentary assembly of 128 seats is divided into 64 seats for Christians, of which 1 seat is held by Christian minorities and Jews and 64 seats for Muslims. A previous election had been planned in 2013 but the conflict regarding the Syrian civil war and disagreements between the major's parties and members of the parliament prolonged the negotiation process until an agreement was found in 2017. The elections in 2018 marked a turning point in Lebanon with the defeat of the pro-western and pro-Saudi Saad Hariri bloc, an alliance between a Sunni, Maronite and Druze party after 13 years of domination and the rise of proSyrian parties such as Amal, Hezbollah and the Azm Movement on the Muslim side. On the Christian side, the presidential party, formed by the Free Patriotic

*Phd Candidate, University of Strasbourg, France. 
Movement and their allies were elected through the majority of votes. This result for the Christians was achieved through a campaign targeting two main points: the refugee crisis and the neutrality of Lebanon in the Middle East.

Choosing football for this research as the possibly most significant sport relies (Archambault et al. 2016) on the fact that it is the most popular sport in Lebanon (Lamloum 2011). In terms of public attendance, participation and broadcasting it exceeds all other sports. It is also a sport practiced by men and women on a regular basis. From September until May people can watch football matches in stadiums or on TV almost every weekend. This sport with its participation of men and women holds the potential to show the multiple ways in which the Lebanese society organizes its leisure and work time around a sport. This study exclusively considers football clubs with teams in the first division of men's and women's championships and high level performers within these ranks such as players and coaches. Since the first division of football in Lebanon is highly dominated by Sunni and Shia regarding clubs, players and supporters, it is therefore the most obvious and evident example of a sport that holds the potential to reveal links and reflections about the historical and present tension between the Sunni and Shia communities which is and has been the most dominating conflict within the Lebanese society and politics since 2005 and the death of Lebanon's prime minister Rafic Hariri who died through a car bomb.

Football is also a sport with one of the highest financial funding. A case which is generally a rare phenomenon in Lebanese sports (Nassif and Amara 2015). Moreover the geography of Football and its effective influence is larger than any other sport in Lebanon and reaches a highly complex variety of urban settings. Especially in comparison to Basketball which is similarly popular and well financed sports (McClenahan 2007) but is concentrated on a much smaller scale of territory throughout Lebanon and would accordingly display a less refined link to the political landscape.

\section{Geography of Clubs, Games and Training}

If practice is considered as a key element and essential base of a performance level, appropriate and sufficient places to do so are not always easy to find in Lebanon. Although men clubs which form twelve teams in the first division, have access to their own training fields, only one women team out of eight has access to a constant training facility. This circumstance is simply related to the budget of the clubs. Even though men do have their own facilities, most of these are old stadiums which can only be used for training but don't fulfil the standards required for official matches. Although the clubs' seats are concentrated in and around Beirut, this city which is densely built within its stretched limits barely provides any sport facilities such as training fields and doesn't leave space to build new ones. Regarding clubs outside the metropolitan area of Beirut, a stadium complying with the standards required exists in the cities of each club except for two clubs in the south of Lebanon, Tadamon Sour and Al Islah Al Bourj Al Shemaly which share the Tyre Stadium. 


\section{Sectarian and Political Affiliation of Clubs}

Due to the lack of funding by the state and lack of revenues through broadcasting and ticketing, clubs are obliged to commit to private companies or political leaders as sponsors. The same setting is the case for Lebanese TV channels and newspapers (Corm 2012). Furthermore clubs not only show political but also sectarian affiliations. As an example, during the season of 2017/2018 in the men's $1^{\text {st }}$ division, 4 Shia clubs, 3 Sunni clubs, 3 Druse clubs, 1 GreekOrthodox club and 1 Maronite club participated. While men clubs reach higher public popularity and receive better funding, the aspect of sectarian affiliation within the women clubs is different. Only two out of eight claim a clear sectarian affiliation, 1 Maronite club and 1 Druse club. Analysing the structure of the rest of the women teams, whose players affiliate with different confessions within each, leisure, gender and business studies play a more relevant role (Deeb and Mona 2007). In comparison to men teams which depend on their clearly affiliated sponsors, women teams and their lack of private funding allow a space in which the sport is mostly pursued out of passion. Out of eight women teams in the $1^{\text {st }}$ division, only two clubs granted a salary of a few hundred dollars per month for the best Lebanese players and a few foreigners. The rest of the clubs only offer foreign players a job or the amount of their residential rent.

\section{Statutes of Clubs and Players}

While women cannot make a living from their passion, men cannot earn more than the average granting in the Lebanese $1^{\text {st }}$ division which is settled between $500 \$$ and $2500 \$$ per month. Unlike most European and Asian championships, the Lebanese premier league is not considered a profession by the Lebanese law. In order to practice football or others sports in Lebanon, a membership of a sports association (non-profitable association with its main focus on sport) is required. Another option is to be part of a private company's club as a customer or employee. Four out of eight women teams in the first division in Lebanon are affiliated with private sport academies. Considering the leisure, gender and business studies are a key tool to understand the sociological development of the women sports' situation in Lebanon which changed from women playing football being perceived as a weird or scandalous event ten years ago to the football program for women in most of the Lebanese university campuses of today. In terms of gender equality this can be considered as a progressive result. Still it has to be noted that the age range of the large majority of girls and women playing football settles between 15 and 23 towards the end of their university attendance. Adding the fact that most of Lebanese universities are private universities and only $39 \%$ of Lebanese students are inscribed in public universities (Hafez 2008), football clubs can be considered as a privilege for middle and upper class women regardless of their confession or political affiliation. 


\section{Literature Review}

Prior and relevant literature that was used as a foundation for this article states that throughout the historical development of Football, Lebanon witnessed three waves of Football club foundations. The first of them consisted of Christian clubs during the French mandate over Lebanon and Syria in the 1920s. The second one was formed through Sunni and Druze clubs in the 1960s and the last one through Shia clubs in the 1960s (Moroy 1998, 2000). Since the Post-civil war period the Basketball federation has been controlled by Christians whereas the Football federation has been controlled by Muslims which displays an exemplary result of the territorial shifting of population that took place during and after the civil war leading up to a reality in which sports became a sect property (Blanc 2005). Analysing the distribution of seats inside sports federations it is shown that the structure of confessionnalism is recreated within their organizations (Nseir 2012). Beirut, the capital of Lebanon forms a macrophage entity which leads to the consequence of clubs settling their headquarters in and around Beirut (Moroy 1998, 2000). Inspite of the economic power of the capital a lack of investment in the infrastructures of sports and the ghettoization of sports is the defining case in Lebanon. Although sport infrastructures are built with European standards, they are not sustainable because of a lack of maintenance policies and continuous investment (Nassif 2013).

Additionally the preceding literature treats the issue of denominational clubs and cities without populations mixing due to the post-war society's territorial shifting of sects during the civil-war (Blanc 2005). During the Post-civil-war period, ritualized clashes between Christians and Muslims were seen in and around the topic of sports as well as political leaders of both confessions, mostly Sunni and Maronite sects, competing in their power over sports in the early 90s. (Reiche 2011) In 2005 after the death of Lebanon's prime minister Rafic Hariri through a bomb attack, violent clashes took place in stadiums. This created one of the most important turning points in Lebanese post war history. Following this event Lebanon was not as clearly divided between Muslims and Christians anymore as before but furthermore divided between followers and opponents of the Syrian regime which formed the post-civil war peace-keeping force but was also presumed guilty for Hariri's death. The 2009 parliamentary election ended a period of four years of tension by a divided assembly between the $8^{\text {th }}$ and $14^{\text {th }}$ of March which consisted of the two political movements voting pro and against Syria (Lamloum 2011). During the time of the parliamentary election in 2009 officially no clubs belonged to a political party (Lamloum 2011).

\section{Methodology}

For the field research, football areas such as training fields, stadiums and club's headquarters and their surroundings were visited on site and searched for political traces such as posters, flags, banners, wall paintings with religious or political symbols and slogans. Additionally game schedules were followed, 
training sessions and live matches were attended to step into direct engagement with the world of football (Stroeken 2002) and to observe the atmosphere, the social and professional interactions, attitude, behaviour and perceptions within the teams, organizations and fan communities. To add to the observations and refine the perspective of an outsider onto the complex nature of its social and political life, various researchers on the topic, journalists, players, coaches, staff and fans were interviewed individually. Formally and informally through conversational interviews in a face to face researcher - participant setting, discussing issues and asking questions about usual and unusual events (Piercey 2016). With the empirical method the data found in the media such as television, newspapers, online networks and communities and social media were gathered and critically analysed. Data were obtained from the official websites of the Lebanese government and analysed for possible links and correspondence between the various structures within the football scene and the geographical division of circumscription regarding the parliamentary elections in 2018.

\section{Findings}

Map of the Lebanese Football Stadiums and the Political Division of the Country

Electoral map 2018 and stadiums: Who surrounds the football stadiums? This map shows (see Figure 1) the 15 voting districts of the parliamentary elections in 2018. It also shows the repartition of the majoritarian confessions in Lebanon divided by district. Although the map doesn't show the minorities living inside a district, it displays a precise picture of the ruling confession of it.

Moreover one can see the football stadiums which were used by the clubs this year. There are only 9 stadiums although there are 12 clubs. Infrastructure is one of the weakest points. With 11 constituencies, 18 clubs and 8 stadiums in the West compared to only 4 constituencies, 2 clubs and 1 stadium in the East, the map clearly displays a dominating amount of stadiums in West Lebanon compared to the East on the same size of territory.

After visiting all of the shown regions and stadiums (Table 1), it was found that the surroundings of all the stadiums showed political signs (flags, posters, etc.) with similar affiliations to the dominating ones of the region. Before the elections in 2018 the country was ruled by a parliamentary block formed by the Sunni party of Saad Hariri and his Christian and Druze allies. It has to be mentioned that already during the preceding season before the elections in 2018 while the Hariri block was still ruling, a balance between the affiliations of men's clubs to the competing political parties was already established as shown on the following Table 1. 
Figure 1. 2018 Lebanese Constituencies and $1^{\text {st }}$ Men Division Football Stadium



Source: ( http://www.middleeasteye.net (MEE/Graphics).

Table 1. Club, Location, Sectarian and Political Affiliation

\begin{tabular}{|l|}
\hline \multicolumn{1}{|c|}{ Clubs affiliated to Saad Hariri and his allies: } \\
\hline Al Nejmeh (Beirut, Sunni with supporters from Sunni, Shia and Druze fans) \\
\hline Al Ansar (Beirut, Sunni) \\
\hline Al Safa (Beirut, Druze) \\
\hline Al Akhaa Aley (Aley, Druze) \\
\hline Racing Beirut (Beirut, Greek-Orthodox) \\
\hline Shahab al Arabi (Beirut, Druze) \\
\hline \multicolumn{1}{c|}{ Clubs affiliated to Amal/Hezbollah and their allies: } \\
\hline Al Ahed (Beirut, Shia) \\
\hline Salam Zgharta (Zgharta, Maronite) \\
\hline Tadamon Sour (Sour, Shia) \\
\hline Tripoli SC (Tripoli, Sunni) \\
\hline Al Nabi sheet (Nabi sheet, Shia) \\
\hline Al Islah (Bourj al Chemaly, Shia) \\
\hline Source: Author
\end{tabular}

In all of Lebanon, after the Rafic Hariri's assassination, fans were banned from entering stadiums during games from 2005 until 2011. From 2011 until 2017 and the current season, fans of visiting teams were forbidden to attend the matches and only "home" fans were allowed. The term "home" fans is put in quotation marks since at least three teams in Beirut don't have their own stadium and all 
teams played their "home" games depending on the opponent's fandom size of a Beirut based team. To demonstrate with an example, the current champion al Ahed played their home games during this season 7 times in the Camille Chamoum Stadium in Beirut which is the biggest stadium in Lebanon, twice in the Saïda International Stadium in Saïda in the south of Lebanon, twice in the Al Ahed Stadium in the southern suburbs of Beirut which is their original home stadium. This repartition of the home games is common and shared by all clubs from Beirut. In return, teams which are not part of the metropolitan area of Beirut played their games in their own stadiums, commonly in the city where their club is based, except Al Islah which played their games in the Sour Stadium because Sour (Tyre) and Islah are cities located right next to each other.

To come back to the public attendance at games, only four teams receive more than a thousand of spectators per game: Salam Zgharta, Al Nejmeh, Al Ansar and $\mathrm{Al}$ Ahed. If we take a closer look at the details, only $\mathrm{Al}$ Nejmeh can claim to receive more than ten thousand spectators at each home game (Cadiot 2015). In the case of matches between the most popular teams, the match takes place in the Camille Chamoum Stadium to divide the supporters for safety reasons. Furthermore these four most popular teams display most evidently the support from a political and religious background.

A strong example of the power of a community surrounding a club is the Maronite Christian club Salam Zgharta. Located in the northern part of Lebanon, Zgharta is the last Christian district before the northern Muslim part of Lebanon and the city of Tripoli. Despite the majority of Maronite inhabitants, the district is not politically dominated by any of the three Christian Maronite main parties. Instead it is dominated by the Frangie family who is tied to the Al Assad family who rules Syria. In the 2018 elections, the parliamentary seats of the Zgharta district were won by the Marada party who is controlled by the Frangie family.

Concerning football, the Salam Zgharta club has its own field located in their city. Highly attended, the club is led by a Maronite priest: Estephan Frangié. According to Dr Souto, an assistant professor of Sociology at the Antonin University in Lebanon, Frangié regularly complains about the Muslims' domination of the football federation in the media. This dichotomy between the Frangie family being affiliated with the Syrian ruling family and a priest of the Frangié family complaining about Muslims puts the club in a unique situation.

Within all the academic researches on the topic of football, the Al Ahed club which currently holds the position of champion has been the most studied one because of its political and financial link with the Hezbollah party. During the civil war period the Hezbollah party took over the Al Ahed club from an old Shia family in Beirut. After the end of the civil war the party released most of the positions on the club's board which had been occupied by party members, only keeping the position of general secretary occupied by a member of the Hezbollah party. Nonetheless people involved with the club's activities and fans are known to be clear supporters of the party and its main public figure Hassan Nasrallah. Their stadium is located in the southern suburbs of Beirut as well as the headquarters of the party. Flags of Hezbollah, portraits of martyrs from the Syrian civil war in which Hezbollah is actively involved in mark the area. According to Lamloum 
(2011), during the games of Al Ahed flags of the party are forbidden. However, during important games the clubs' flags and Hezbollah flags which both share the colours yellow and green, mix on their supporters' side of the stadium.

The case of publicly displayed political flags in a stadium is equally observed during games of the Al Ansar team. The former Lebanese champion of the years between 1990 and 1999, used to be the figurehead of Rafic Hariri's domination in the post-war sport scene. With a loyal fandom, Al Ansar is the second club affiliated to the Saad Hariri party regarding popularity. While Al Ansar is a mainly a Sunni club, Al Nejmeh, the first club in terms of popularity and affiliation to Saad Hariri's party is supported by fans of diverse communities such as Sunni, Shia, Druze and Armenian. Moreover it is the most popular sport club in Lebanon. Until the year of 2003 it had formed a club without a strict sectarian background or affiliation, led by a charismatic president: Omar Ghandour. In 2003 Rafic Hariri became president of Al Nejmeh and slowly opposed a growing Sunni affiliation to the club. During the parliamentary elections in 2009 and 2018, certain political candidates for the Beirut II constituency tried to use their personal history of involvement in the club to gain popularity.

Around the Rafic Hariri stadium of Al Nejmeh in Beirut-Manara, the only posters observed were affiliated to Saad Hariri, whereas around the municipal stadium which is also located in the Beirut II constituency, posters of Omar Ghandour, the political opponent of Saad Hariri, were displayed on walls. Throughout the history of Al Nejmeh until today, the club has allowed a multiconfessional system within its structure and shown recognition of fans who don't share its political and sectarian affiliation.

\section{Women Football}

Compared to the men's matches who show the potential of attracting thousands of spectators, the women teams' situation is quite different. The average number of spectators during a women championship is settled between 100 and 300 per match. Although women football is witnessing a clear rising in popularity and attendance of the sport, the research showed that the duration of the women's championship compared to men's only lasts 4 months instead of a whole year which is not only the case in football but in all other sports as well. While in other sports this case is a result of diverse reasons, in football the main reason for a shorter season is the lack of players over the age of 23 . In order to play all year long women have to play two sports, football and futsal unless they are younger than 19 years old.

For girls and women between the ages of 15 and 19 two championships take place throughout the whole year. The first one is the senior championship which includes the U19 players from September until December and second one is a youth championship for only U19 players. After the age of 19, women have to play futsal during the second part of the season if they want to continue to play. Girls and women show their highest attendance in football between the age of 15 and 19 . Between the ages of 19 and 22/23 they switch to futsal and vice versa. 
When questioned about their teammates and opponents, $80 \%$ of the girls and women said that they were fellow students from high school or university. After the age of 23 the involvement of women in football and futsal shows an extreme decline, an age when most students finish university. In an education system built on a majority of private schools and universities, women football in Lebanon can be considered a sport for the middle and upper-class regardless of the confession.

Another reason for the declining numbers of players after the age of 23 is the highly regarded norm in Lebanese society to form a family and have children. It is very uncommon for a woman around the age of 30 to still live in her parents' home. To quote a player from a women team: "They don't take football seriously, because here when they finish the university look for having a family they don't have time anymore for football'. Further observations throughout the field research showed that almost all the active women players are younger than 28 and that almost all of the staff members are men.

Additionally none of the women clubs and teams is based in central Beirut. 5 teams are based in the outer metropolitan area of the capital, 2 are based in the northern cities of Zgharta and Tripoli where football is highly popular and 1 is located in Jabal El Sheikh in the south east close to the Israeli and Syrian borders.

According to George Nseir (2012) compared to Christian constituencies, the importance of football regardless of gender is displayed more strongly in Muslim constituencies. However the financial perspectives of continuing to play football do not hold opportunities for women whereas men get paid enough to consider football as a professional activity although it is not considered a profession by law.

\section{Results}

Which links appeared between the maps, the field research and the sectarianism in politics and football clubs? The world of football in Lebanon with its supporters, clubs and stadiums is consistently dominated by Muslims. Before the elections in 2018 the main political parties agreed on the new division of voting districts within the electoral map shown in Figure 1 of this study which corresponds to stadiums and clubs dominantly located in Muslim constituencies. As an example the Druze community makes out only $4.5 \%$ of voters in Lebanon, while having six football teams out of twenty and therefore $30 \%$.

A similar case is found in basketball with two Armenian clubs as champions in men and women basketball while the Armenian community only makes out $4 \%$ of voters in Lebanon. Moreover the map in Figure 1 displays the lack of infrastructure and the concentration of stadiums in the coastal regions. Only two football teams drift off the occidental slope of Mount-Lebanon. One of men's team, $\mathrm{Al} \mathrm{Nabi}$ is located in the northeast part of the Beqaa Valley and one of women's team, the Jabal El Sheikh is based in the southeast of Lebanon. The nonproportional amount of sport involvement and infrastructure in the West of Lebanon can be assumed to reflect the social importance of sports as well the political involvement in that region. Moreover the results of this study lead to the 
assumption of sports being a tool in Lebanon to increase and reinforce the political standing of a community.

The research of Lamloum (2011) showed that spatial football identities reinforce political areas. This statement was confirmed by the observations of this field research 7 years later. Without exception, sectarian or political signs were found in or around every stadium. During the election of 2018 when candidates of different parties had posters hanging in a variety of cities, it was observed that posters of political opponents were torn down in the surrounding areas of stadiums.

Within the stakeholders in football and their socio-organizational functions, three ideal types appear. The first category is formed by politicians and their partnering board members of a club. In return for their financial investment, politicians receive a symbolic profit in return. The second category consists of journalists (see Table 2) and staff members of a club. These act as spokespersons of the political party affiliated to the club and self-sufficient operators of the football scene. They demonstrate a strong support of their club in interviews and other forms of media (Gonzalez-Quijano 2014) while criticizing opponent clubs openly. The third category is based on players who try to keep a neutral distance to their club's official affiliation and public discourses. With the perspective of a short career, low financial profit and a material dependence on football, men players rather strive for recognition on a sport's level.

Concerning the financial perspective, women players are divided between foreigners, a maximum of two per team as regulated by the federation, who can be considered as semi-professional with a salary of a few hundred dollars and an elite of Lebanese players who earn the same amount as foreigners, additionally playing for the national team and a majority covering all of the costs individually. To resume these results, while collective groups of participants in football are working together with politicians, a significant group of stakeholders formed by the players try to operate as independently as possible within the boundaries of their clubs.

Table 2. Sectarian Affiliation of Clubs Stated by Sports Journalists

\begin{tabular}{|c|c|c|c|c|c|}
\hline$\frac{\text { Women }}{\text { Football }}$ & & $\begin{array}{c}\text { Akhaa ahli } \\
\text { Aley (w) / } \\
\text { Jabal Sheikh }\end{array}$ & $\begin{array}{c}\text { Salam } \\
\text { Zgharta } \\
(w)\end{array}$ & Tripoli & $\begin{array}{c}\text { SAS / } \\
\text { O'Berytus / } \\
\text { Sporting high } \\
\text { /Zouk Mosbeh }\end{array}$ \\
\hline$\underline{\text { Men }}$ & $\begin{array}{c}\text { Al Ahed / Al } \\
\text { Islah / Al Nabi } \\
\text { Sheet / *Nejmeh } \\
\text { SC / Tadamon } \\
\text { Sour }\end{array}$ & $\begin{array}{c}\text { Akhaa Al } \\
\text { Ahli Aley / } \\
\text { Al Shabab al } \\
\text { Arab / Al } \\
\text { Safa }\end{array}$ & $\begin{array}{l}\text { Salam } \\
\text { Zgharta }\end{array}$ & $\begin{array}{l}\text { Al Ansar / } \\
\text { Nejmeh } \\
\text { SC / } \\
\text { Tripoli SC }\end{array}$ & Racing Beirut \\
\hline
\end{tabular}

Source: Author. 


\section{Discussion}

This article introduces a brief attempt to discover links between politics and football in Lebanon. The main focus having been to recognize political arrangements through the structures of high league football clubs, it would be interesting to do further research about the counter perspective. To understand which persons in the sports world might play roles in politics, what their exact role in football is and what it might have been in the past.

It can be questioned if the collected empirical data was not analyzed and structured deeply enough and if a further study of it might change the conceptual results of this research.

Considering the relatively small amount of individual interviews with up to 20 people from different parts and levels of the football scene, a sociological study on a larger scale and a period of multiple consecutive years might complete or contradict the results of this research and/or expose further perspectives.

To enhance this study it should also be considered to compare the link between football and the parliamentary elections with a study on other high league sports in Lebanon. To see if similar or different links exist and if they might create a larger contextual understanding of the topic.

\section{Conclusions}

In high level of the Lebanese football scene, politicians play dominating roles without occupying official positions in the sport itself. As Lamloum (2011) stated, during the 2009 parliamentary elections, no clubs officially belonged to a political party. There are two types of legal structures within the championship of the first division of men and women in Lebanese football: The first one is the model of clubs based on the structure of a sports association. This model is applied on 16 teams, all of the 12 men teams and 4 women teams. The second model builds clubs with the structure of private sport academies. This model is applied to 4 women teams only. Since the entrance fee for a membership of an association can be determined by the board without limitations and is therefore mostly settled very high, it is a tool to control the potential influence of members. But in a society based on the structure of cronyism (Al-Masri 2016), (Amara 2014), (Nassif and Amara 2015) and (Salamey 2009), political leaders and business people who are able to finance and afford football are working together (Reiche 2011) (Nseir 2012). The political structure of Lebanon and its confessionnalism is repeated and applied within the structure of Football. Resuming the brief comparative between football clubs and the 2018 parliamentary elections, a restabilised situation in favour of the Shia in relation to the Sunni is the case. Due to the post-civil war domination in football by the Sunni and their allies, the map of the stadiums still displays a Sunni dominated presence in football. Nevertheless in terms of men teams and a comparison to the Sunni affiliated club Al Ansar, which has not won any titles during the last 10 years, Hezbollah and their club $\mathrm{Al}$ Ahed which has won 6 titles, is the dominating party in the football scene, followed by the Druze 
and their team Al Safa with 3 titles. Al Nejmeh achieved two titles during this period but even if the current structure reflects a pro Sunni and Saad Hariri orientation cronyism (Al-Masri 2016), regarding the diversity of its fandom and history, the club cannot be considered purely Sunni. Regarding women football, this study showed a Druze interest in women playing football in their area but a further study would be needed to collect confessional and location background of all the players and staff since dominantly Druze areas are inhabited by relevant numbers of other confessions. Furthermore it would have to be studied if the interest is rooted in the community or simply a result of certain economic transactions between stakeholders within the women football. With the result of the elections in favour of the Shia Hezbollah party and their allies - the Maronite Christian party of the president Michel Aoun, it should be furthermore observed if the infrastructure of football will change accordingly and if the weakened Sunni party and their Druze allies will use football to reinforce their political power.

\section{References}

Hafez AS (2008) Quel environnement francophone pour le français au Liban?[ What French environment for French in Lebanon?]. Beyrouth: Université Libanaise .

Al-Masri M (2016) Political Theatre: Football and Contestation in Beirut. Beyrouth: American University of Beirut.

Amara M (2014) Sport and Political Leaders in the Arab World. Histoire@Politique: 142-153. doi: 10.3917/hp.023.0142.

Archambault F, Beaud S, Gasparini W (2016) Le football des nations[Nations football]. Paris: Publications de le Sorbonne.

Azzam C (2015) Lebanon. (I. C. Research, Hrsg.) Counter Terrorist Trends and Analyses 7(1): 71-74.

Blanc P (2005) Le sport au Liban : un révélateur de la société. les Cahiers de Confluence: $159-161$.

Cadiot J (2015) Le peuple de Nejmeh [The people of Nejmeh]. Retrieved from https://bit. ly/2Ay99v9.

Corm G (2012) Le Liban contemporain : histoire et société [Contemporary Lebanon: history and society]. Paris: La Découverte.

Deeb L, Mona H (2007) Sanctioned Pleasures: Youth, Piety and Leisure in Beirut. Middle East Research and Information Project, Hrsg. Middle East Report(245): 12-19.

Gonzalez-Quijano Y (2014) Les identités collectives arabes au temps d'Internet et des réseaux sociaux[Arab collective identities in the age of the Internet and social networks]. Revue internationale et stratégique: 91-99. doi:10.3917/ris.093.0091.

Lamloum O (2011) Le Hezbollah libanais et le football: divertissement pieux et socialisation politique[Lebanese Hezbollah and football: pious entertainment and political socialization]. In Bozzo A, Luizard PJ (eds). Les sociétés civiles dans le monde musulman, 215-225. Paris: La Découverte.

McClenahan W (2007) Lebanese sports from a basketball perspective. Master thesis in American University of Beirut.

Moroy F (1998) Football et communautarisme à Beyrouth. Sociétés et représentations 2(7): 155-162. doi: 10.3917/sr.007.0155. 
Moroy F (2000) Le sport comme adjuvant à l'action politique. Le cas du Hezbollah à Beyrouth[Sport as an adjunct to political action. The case of Hezbollah in Beirut]. Politix Deuxième trimestre 2000 13(50): 93-106. doi :10.3406/polix.2000.1088.

Nassif N (2013) Analyse de la politique du sport au Liban de 1991 à 2012[Analysis of sport policy in Lebanon from 1991 to 2012]. Grenoble: Ecole Doctorale Ingénierie pour la Santé, la Cognition et l'Environnement.

Nassif N, Amara M (2015) Sport, policy and politics in Lebanon. International Journal of Sport Policy:1-15. doi: 10.1080/19406940.2014.914553.

Nseir G (2012) Des communautés et des sports au Liban : Enjeux des regroupements sportifs et des rencontres intercommunautaires[Communities and sports in Lebanon: Challenges of sports groups and intercommunity meetings]. Strasbourg: Ecole doctorale "Sciences Humaines et Sociales : Perpectives européennes".

Piercey N (2016) Constructing football discourses: the media and early Dutch football. In N. Piercey (ed) Four Histories about Early Dutch Football 1910-1920, 107-138. London: UCL Press.

Reiche D (2011) War Minus the Shooting? The politics of sport in Lebanon as a unique case in comparative politics. Third World Quarterly 32(2): 261-277. doi: 10.1080/ 01436597.2011.560468.

Salamey I (2009) Failing Consociationalism in Lebanon and Integrative Options. International Journal of Peace Studies 14(2): 83-105.

Stroeken K (2002) Why 'The World' Loves Watching Football (And 'The Americans' Don't). (R. A. Ireland, Hrsg.) Anthropology Today 18(3): 9-13. doi: 10.1111/14678322.00119 . 
